\title{
DAYA HAMBAT EKSTRAK HEKSAN, ETIL ASETAT DAN ETANOL DARI \\ DAUN ASAM KANDIS (Garcinia parvifolia (Miq.) Miq.) TERHADAP AKTIVITAS ENZIM $\alpha$-GLUKOSIDASE SECARA IN VITRO
}

\author{
Min Rahminiwati, Ike Yulia Wiendarlina, Ceristianto \\ Program Studi Farmasi, FMIPA, Universitas Pakuan, Bogor \\ Email:minrahminiwati@yahoo.com
}

\begin{abstract}
ABSTRAK
Salah satu penyebab peningkatan kadar gula darah pada penderita penyakit diabetes mellitus adalah tingginya aktivitas pemecahan karbohidrat menjadi glukosa oleh enzim $\alpha$-glukosidase. Beberapa penelitian menunjukan bahwa daun asam kandis diketahui memiliki kandungan senyawa xanthone yang mampu menghambat aktivitas enzim $\alpha$-glukosidase. Penelitian ini bertujuan untuk mengetahui aktivitas antidiabetes ekstrak heksan, etil asetat dan etanol daun asam kandis (Garcinia parvifolia (Miq.) Miq.) dengan mengukur daya hambat ekstrak daun asam kandis terhadap aktivitas enzim $\alpha$ glukosidase secara in vitro. Pengujian daya hambat terhadap aktivitas $\alpha$-glukosidase dihitung berdasarkan nilai $\mathrm{IC}_{50}$ dengan senyawa acarbose sebagai pembanding (kontrol positif). Hasil uji daya hambat ekstrak daun asam kandis terhadap aktivitas enzim $\alpha-$ glukosidase menunjukan bahwa aktivitas inhibisi ( $\mathrm{IC}_{50}$ ) dicapai pada pemberian ekstrak heksan, etil asetat dan etanol daun asam kandis berturut-turut sebesar 226,4 $\pm 24,18 \mathrm{ppm}$, $46,96 \pm 10,48$ ppm, dan 7,32 $\pm 2,14$ ppm. Dari hasil penelitian dapat disimpulkan bahwa ekstrak etanol berpotensi paling tinggi sebagai inhibitor enzim $\alpha$-Glukosidase.
\end{abstract}

Kata Kunci: Antidiabetes, asam kandis, inhibitor $\alpha$-glukosidase

\section{INHIBITORY CAPACITY OF HEXANE, ETHYL ACETATE AND ETHANOL EXTRACTS OF ASAM KANDIS LEAF (Garcinia parvifolia (Miq.) Miq.) ON $\alpha$ - GLUCOSIDASE ENZIME IN VITRO}

\begin{abstract}
Diabetes mellitus is a metabolic disorder resulting from defects in insulin secretion, and/or insulin action. The disease characterized by a chronic hyperglycaemia with long-term damage, dysfunction, and failure of various organs. Previous studies reported that the leaves of asam kandis (Garcinia parvifolia (Miq.) Miq.) contain xanthone compound which could act as an inhibitor of $\alpha$-glukosidase enzyme. The aim of this study was to determine the antidiabetic activity of hexane, ethyl acetate and ethanol extract of asam kandis leaf by measuring an the inhibitory effect of asam kandis leaf extracs on $\alpha$-glucosidase activity in vitro. The inhibitory activity of asam kandis leaf extracts was calculated based on value of $\mathrm{IC}_{50}$. The acarbose was used as a positif control. The present results showed that the $\mathrm{IC}_{50}$ was achieved at addition of $226.4 \pm 24.18 \mathrm{ppm}$, $46.96 \pm 10,48 \mathrm{ppm}$, and $7.32 \pm 2.14 \mathrm{ppm}$ hexane, ethyl acetate and ethanol extracts of asam kandis leaf respectively. This results confirmed that the ethanol extract had the highest potential antidiabetic activity as an inhibitor of $\alpha$-glucosidase activity.
\end{abstract}

Keywords: Antidiabetic, Garcinia parvifolia, $\alpha$-glucosidase inhibitor

\section{PENDAHULUAN}


Diabetes Mellitus atau penyakit kencing manis adalah kelainan metabolik yang disebabkan oleh banyak faktor seperti kurangnya insulin atau ketidakmampuan tubuh untuk memanfaatkan insulin. Penyakit ini ditandai oleh hiperglikemia kronis berupa gangguan metabolisme karbohidrat, lemak dan protein. Efek dari Diabetes Mellitus meliputi kerusakan jangka panjang, disfungsi dan kegagalan berbagai organ. Penyakit ini dapat muncul dengan gejala khas seperti haus, poliuria, penglihatan kabur dan penurunan berat badan (WHO, 1999).

Pengobatan Diabetes Mellitus biasanya dilakukan dengan pemberian suntikan insulin atau dengan obat-obat Oral Anti Diabetik (OAD) yang meliputi golongan sulfonilurea, biguanid, thiazolidinedion, dan inhibitor alfaglukosidase (Silva, 2004). Inhibitor alfaglukosidase telah digunakan dalam pengobatan untuk mengatasi Diabetes Mellitus tipe 2. Obat ini bekerja melalui penghambatan kerja alfa-glukosidase secara reversibel, suatu enzim yang ada dalam dinding usus halus. Penyerapan karbohidrat kompleks ditunda oleh obat ini dan dengan demikian puncak glukosa postprandial menjadi terhambat (Laar et.al.,. 2005).

Berbagai jenis obat antidiabetik oral banyak ditemukan di apotek dan biasanya tergolong obat yang mahal. Penggunaan obat ini dilakukan terus menerus, hingga bagi yang tidak mampu sulit memperolehnya. Disamping itu di daerah yang tidak mempunyai apotek, obat untuk penyakit ini sulit ditemukan. Untuk itu perlu dicarikan alternatif yang salahsatunya adalah menggunakan tanaman obat (Widowati et al.,. 1997).

Asam kandis (Garcinia parvifolia (Miq.) Miq.) termasuk ke dalam famili Clusiaceae. Tumbuhan ini merupakan spesies tropis yang ditemukan liar di hutan rawa gambut. Di Indonesia daun muda kemerahan asam kandis dimakan sebagai lalap dan karena memiliki rasa asam sering digunakan dalam sayur sebagai pengganti asam. Tanaman yang termasuk ke dalam genus Garcinia ini diketahui banyak mengandung senyawa xanthone (Lim, 2012). Hasil penelitian menunjukkan bahwa turunan xanthone mampu menghambat $\alpha$-glukosidase secara in Vitro dengan aktivitas sedang hingga baik (Liu et al.,. 2006).

Penelitian ini bertujuan mempelajari aktivitas penghambatan berbagai ekstrak daun kandis terhadap aktivitas $\alpha$ glukosidase yang dilakukan secara in vitro. Aktivitas inhibisi $\alpha$-glukosidase dari berbagai ekstrak daun asam kandis untuk membuktikan manfaatnya sebagai antidiabetes dinyatakan dalam $\mathrm{IC}_{50}$ yaitu konsentrasi yang dapat menghambat $50 \%$ aktivitas enzim.

\section{METODE PENELITIAN \\ Bahan dan Alat}

Bahan-bahan yang digunakan pada penelitian ini adalah daun Garcinia parvifolia (Miq.) Miq., akuades, etanol $96 \%$, etil asetat, heksan, enzim $\alpha-$ glukosidase (Sigma), Substrat $p$-nitrofenil$\alpha$-D-glukopiranosida (PNG) (Sigma), larutan buffer fosfat ( $\mathrm{pH} 7$ ), serum bovine albumin (Merck), acarbose (Bayer), dimetilsulfoksida (DMSO), $\mathrm{HCl} 2 \mathrm{~N}$, dan $\mathrm{Na}_{2} \mathrm{CO}_{3}$. Bahan-bahan yang dipakai untuk uji fitokimia adalah kloroform, ammonia, $\mathrm{H}_{2} \mathrm{SO}_{4} 2 \mathrm{M}$, pereaksi (Dragendorff, Mayer \& Wagner), serbuk $\mathrm{Mg}, \mathrm{HCl}$ pekat, amil alkohol, asam asetat anhidrat, $\mathrm{H}_{2} \mathrm{SO}_{4}$ pekat dan $\mathrm{FeCl}_{3} 1 \%$.

Alat-alat yang digunakan adalah penangas air, neraca analitik, rotary evaporator, corong pisah, pipet mikro, pipet volumetrik, pipet tetes, labu Erlenmeyer, tabung reaksi, gelas piala, gelas ukur, bulp, batang pengaduk, sudip, corong gelas, kertas saring, sentrifus, microplate 96 well dan microplate reader (Epoch). 


\section{Pembuatan Simplisia}

Daun asam kandis sebanyak $1.5 \mathrm{~kg}$ dibersihkan dari kotoran yang menempel, kemudian dicuci bersih dan dikeringkan di bawah sinar matahari secara tidak langsung sampai kering kemudian digiling dan diayak menggunakan ayakan mesh 20 (DepKes RI, 1985).

\section{Analisis Karakteristik Serbuk Simplisia}

Analisis karakteristik serbuk simplisia dilakukan dengan mengukur kadar air dan kadar abu, dilakukan dengan dua kali pengulangan.

\section{Pembuatan Ekstrak}

Ekstrak dibuat dengan metode maserasi bertingkat menggunakan pelarut heksan, etil asetat dan etanol. Sebanyak $500 \mathrm{~g}$ serbuk simplisia daun asam kandis dimasukkan ke dalam bejana, kemudian dituangi $75 \%$ bagian pelarut heksan setara dengan 3,5 liter. Campuran didiamkan selama 1 hari sambil dilakukan pengocokan 3 jam sekali agar terdistribusi merata, disaring dan diperas. Ampas dicuci dengan pelarut heksan $25 \%$ bagian setara dengan 1,5 liter, dipindahkan ke dalam bejana tertutup, dibiarkan ditempat sejuk dan terlindung dari cahaya selama 24 jam. Endapan kemudian dipisahkan, maserat yang diperoleh dievaporasi menggunakan rotary evaporator hingga diperoleh ekstrak kental daun asam kandis. Rendemen yang diperoleh ditimbang dan dicatat.

Rendemen $=\frac{\text { Bobot ektrak }}{\text { Bobot simplisia }} \times 100 \%$

Setelah didapatkan ekstrak, selanjutnya dilakukan uji fitokimia berdasarkan metoda Rajendra et al., (2011) meliputi uji senyawa alkaloida, uji senyawa flavonoid, uji senyawa saponin, uji steroid-triterpenoid, dan uji senyawa tanin.

\section{Uji Senyawa Alkaloida}

Sebanyak 0,5 g ekstrak diencerkan dengan asam alkohol hingga $10 \mathrm{~mL}$, direbus dan disaring. Filtrat sebanyak $5 \mathrm{~mL}$ ditambahkan $2 \mathrm{~mL}$ ammonia dan $5 \mathrm{ml}$ kloroform dikocok perlahan untuk mengekstrak alkaloid. Campuran diekstraksi dengan $10 \mathrm{~mL}$ asam asetat. Lapisan kloroform dibagi menjadi 3 bagian.

a. Uji Dragendroff: Beberapa tetes pereaksi Dragendroff yang ditambahkan ke dalam larutan kloroform, endapan coklat kemerahan menunjukkan adanya alkaloid.

b. Uji Mayer: Beberapa tetes pereaksi Mayer ditambahkan ke dalam larutan kloroform, endapan putih menunjukkan adanya alkaloid.

c. Uji Wagner: Beberapa tetes pereaksi Wagner ditambahkan ke dalam larutan kloroform, endapan coklat menunjukkan adanya alkaloid.

\section{Uji Senyawa Flavonoid}

Tiga metode digunakan untuk menguji flavonoid. Pertama, beberapa tetes $\mathrm{FeCl}_{3} \quad 1 \%$ ditambahkan pada sampel. Warna hijau kehitaman yang dihasilkan menunjukkan adanya kandungan flavonoid. Kedua, beberapa tetes larutan timbal asetat $10 \%$ ditambahkan pada sampel. Terbentuknya endapan kuning menunjukkan adanya flavonoid. Ketiga, sampel dilarutkan dalam metanol, ditambahkan serbuk magnesium, $1 \mathrm{~mL}$ $\mathrm{HCl}$ pekat ditambahkan dari sisi tabung reaksi. Warna magenta menunjukkan adanya flavonoid.

\section{Uji Senyawa Saponin}

Sebanyak $0.5 \mathrm{~g}$ sampel ditambahkan $5 \mathrm{~mL}$ aquades dalam tabung reaksi. Dikocok kuat-kuat, adanya saponin ditandai dengan terbentuk busa yang stabil. Busa tersebut jika dicampur dengan 3 tetes minyak zaitun akan terbentuk emulsi. 


\section{Uji Senyawa Steroid - Triterpenoid}

Sebanyak $25 \mathrm{mg}$ ekstrak dilarutkan dalam kloroform, disaring dan filtrat ditambah beberapa tetes anhidrida asetat lalu dikocok dengan baik. $1 \mathrm{~mL} \mathrm{H}_{2} \mathrm{SO}_{4}$ pekat ditambahkan dengan hati-hati pada dinding wadah, bila dihasilkan warna coklat kemerahan menandakan adanya steroid, sedangkan cincin berwarna merah menandakan adanya triterpenoid.

\section{Uji Senyawa Tanin}

Sebanyak $0.5 \mathrm{~g}$ sampel direbus dengan $10 \mathrm{ml}$ aquades dalam tabung reaksi, kemudian disaring.

a. Uji $\mathrm{FeCl}_{3}$ : Beberapa tetes $\mathrm{FeCl}_{3}$ 0,1\% ditambahkan pada filtrat, warna hijau kecoklatan atau biru kehitaman menandakan adanya tanin.

b. Uji Gelatin: Beberapa ml larutan gelatin $1 \%$ dalam natrium klorida $10 \%$ ditambahkan pada filtrat, terbentuknya endapan putih menunjukkan adanya tanin.

\section{Uji Aktivitas $\alpha$-Glukosidase}

Aktivitas $\alpha$-Glukosidase diuji berdasarkan metode Irwan (2011). Campuran pereaksi (sampel) terdiri atas 25 $\mu \mathrm{L} \quad p$-nitrofenil- $\alpha$-D-glukopiranosida (PNG) $20 \mathrm{mM}$ sebagai substrat, $25 \mu \mathrm{L}$ larutan bufer fosfat (pH 7) $100 \mathrm{mM}$, dan 50 $\mu \mathrm{L}$ larutan contoh dengan berbagai konsentrasi dalam DMSO (b/v). Campuran tersebut diinkubasi pada suhu $37^{\circ} \mathrm{C}$ selama 5 menit, setelah itu ditambahkan larutan enzim sebanyak $25 \mu \mathrm{L}$ dan diinkubasi kembali selama 15 menit. Reaksi enzim dihentikan dengan menambahkan $\mathrm{Na}_{2} \mathrm{CO}_{3}$ $200 \mathrm{mM}$ sebanyak $100 \mu \mathrm{L}$. Kemudian larutan diukur pada panjang gelombang $400 \mathrm{~nm}$ dengan microplate reader.

Blanko dibuat dari campuran bufer fosfat ( $\mathrm{pH}$ 7) dengan $\mathrm{p}-\mathrm{NPG}$, larutan blanko dan standar disentrifus, supernatan diambil sebanyak $50 \mu \mathrm{L}$ dan dimasukkan ke dalam campuran reaksi seperti dalam sampel. Hasil campuran (sampel, blanko dan standar) tersebut diukur dengan microplate reader pada panjang gelombang $400 \mathrm{~nm}$.

Masing-masing pengujian daya hambat sampel terhadap aktivitas $\alpha$ glukosidase dihitung dalam persen inhibisi dengan rumus sebagai berikut.

$\%$ inhibisi $=\frac{\mathrm{K}-(\mathrm{S} 1-\mathrm{S} 0)}{\mathrm{K}} \times 100 \%$

Keterangan :

$\mathrm{K}=$ Absorbansi terkoreksi dari kontrol positif (enzim + substrat)

$\mathrm{S} 1$ = Absorbansi terkoreksi dari enzim + substrat + inhibitor

S0 = Absorbansi terkoreksi dari substrat + inhibitor

Nilai $\mathrm{IC}_{50}$ (Inhibition Concentration 50) diperoleh dari perpotongan garis antara $50 \%$ daya hambat dengan sumbu konsentrasi menggunakan persamaan $(\mathrm{y}=$ $b x+a)$, dimana $y=50$ dan $x$ menunjukkan nilai $\mathrm{IC}_{50}$.

\section{HASIL DAN PEMBAHASAN Karakteristik Serbuk Simplisia}

Dari 1,5 kg daun segar asam kandis diperoleh serbuk simplisia daun sebanyak 534,8 gram atau sebesar $35,65 \%$ dari berat basah. Serbuk kering daun asam kandis memiiki warna hijau tua (Gambar 1) dan cendrung tidak berbau. Rata-rata kadar air serbuk simplisia adalah 5,61\% (Tabel 1). Nilai ini menunjukan bahwa kadar air yang terkandung dalam serbuk simplisia realtif rendah, dibawah $10 \%$ sehingga waktu simpannya relatif lama dan tidak mudah ditumbuhi mikroorganisme. Kadar air yang rendah juga akan menghindari reaksi enzimatis yang dapat menguraikan zat aktif penyebab penurunan mutu atau perusakan simplisia. 


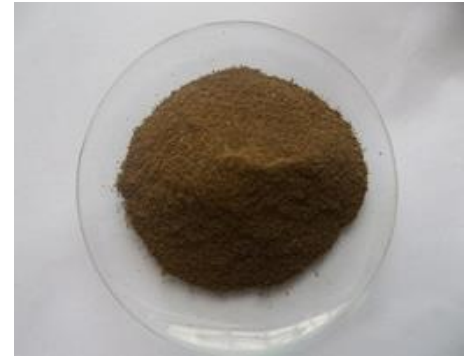

Gambar 1. Serbuk Simplisia Asam Kandis

Kadar abu serbuk daun kandis yang diperoleh rata-rata sebesar 5,54\% (Tabel 1). Hal ini menunjukkan rendahnya kadar zat organik dan mineral yang terdapat dalam serbuk simplisia. Rendahnya kadar abu juga menunjukkan rendahnya cemaran bahan-bahan anorganik yang terdapat dalam simplisia yang terjadi pada saat pengolahan ataupun dalam pengemasan simplisia.

Tabel 1. Hasil Pemeriksaan Kadar Air dan Kadar Abu Total

\begin{tabular}{ccc}
\hline Ulangan & $\begin{array}{c}\text { Kadar Abu } \\
(\%)\end{array}$ & $\begin{array}{c}\text { Kadar Air } \\
(\%)\end{array}$ \\
\hline 1 & 5,29 & 5,34 \\
2 & 5,79 & 5,87 \\
Rerata & 5,54 & 5,61 \\
\hline
\end{tabular}

\section{Ekstrak Serbuk Simplisia}

Hasil rendemen yang diperoleh dari ekstrak heksan, etil asetat dan etanol daun asam kandis adalah 4,07\% 3,97\% dan $12,31 \%$. Tingginya rendemen ekstrak etanol menunjukan hadirnya senyawasenyawa fitokimia bersifat polar pada serbuk daun asam kandis yang larut dalam etanol. Selain itu, polaritas etanol yang tinggi menyebabkan pelarut ini dapat mengekstrak bahan lebih banyak dibandingkan jenis pelarut organik yang lain. Ekstrak kental dari masing-masing pelarut yang diperoleh akan digunakan dalam tahap uji selanjutnya, yaitu uji fitokimia dan uji daya hambat enzim untuk mengetahui ekstrak yang mempunyai daya hambat terbaik terhadap aktivitas enzim $\alpha$ glukosidase.

\section{Hasil Uji Fitokimia}

Dari hasil penelitian diketahui bahwa ekstrak etanol menunjukkan positif mengandung senyawa flavonoid, saponin, tanin, alkaloid, dan steroid. Ekstrak etil asetat menunjukkan positif mengandung senyawa flavonoid, tanin, alkaloid, dan steroid, sedangkan pada ekstrak heksan hanya terdapat alkaloid dan steroid. Pengujian triterpenoid menunjukkan hasil negatif untuk semua sampel. Terlihat bahwa pelarut etanol paling banyak melarutkan senyawa-senyawa bioaktif termasuk flavonoid dan saponin yang berdasarkan penelitian-penelitian sebelumnya diketahui memiliki kemampuan menurunkan kadar gula dalam darah (Hsieh et al., 2010).

Tabel 2. Hasil Uji Fitokimia Sampel

\begin{tabular}{lcccccc}
\hline \multicolumn{1}{c}{ Sampel } & \multicolumn{7}{c}{ Golongan senyawa kimia } \\
& A & B & C & D & E & F \\
\hline - Serbuk Simplisia & + & + & + & + & + & - \\
- Ekstrak heksan & - & - & - & + & + & - \\
- Ekstrak etil asetat & + & - & + & + & + & - \\
- Ekstrak etanol & + & + & + & + & + & -
\end{tabular}

Keterangan: $\mathrm{A}=$ flavonoid, $\mathrm{B}=$ saponin, $\mathrm{C}=\operatorname{tanin}, \mathrm{D}=$ alkaloid, $\mathrm{E}=$ steroid, $\mathrm{F}=$ triterpenoid $+=$ terdapat, $-=$ tidak terdapat

\section{Aktivitas Inhibisi $\alpha$-Glukosidase}


Aktivitas inhibisi ( $\left.\mathrm{IC}_{50}\right)$ ekstrak heksan, etil asetat dan etanol daun asam kandis berturut-turut sebesar 226,4 $\pm 24,18$ ppm, etil asetat 46,96 $\pm 10,48 \mathrm{ppm}$, dan etanol 7,32 $\pm 2,14 \mathrm{ppm}$. Hasil penelitian menunjukkan bahwa ekstrak etanol memiliki aktivitas inhibisi paling tinggi diikuti ekstrak etil asetat dan ekstrak heksan (Gambar 2). Hal ini menunjukkan bahwa, senyawa metabolit sekunder yang berperan sebagai inhibitor alfaglukosidase, memiliki kelarutan tertinggi pada pelarut polar (etanol) diikuti pelarut semipolar (etil asetat) dan pelarut non polar (heksan). Aktivitas inhibisi yang tinggi dari pelarut etanol sejalan dengan hasil uji fitokimia dimana hampir semua senyawa aktif termasuk golongan flavonoid dan saponin larut dalam pelarut etanol. Menurut Smith dan Adanlawo (2012), saponin memiliki aktivitas hipoglikemik melalui stimulasi, sekresi dan pelepasan insulin, regenerasi sel beta pulau langerhans dan aktivasi enzim yang bertanggung jawab untuk penggunaan glukosa, sementara fungsi dari flavonoid adalah untuk menghambat aktivitas enzim $\alpha$-glukosidase sehingga menunda penyerapan glukosa (Havsteen 2002).

Dari hasil uji fitokimia dan uji aktivitas inhibisi enzim $\alpha$-glukosidase, penurunan kadar glukosa darah pada tikus yang diberi ekstrak etanol daun asam kandis kemungkinan disebabkan adanya senyawa saponin dan flavonoid dalam ekstrak etanol tersebut. Hasil-hasil ini menunjukkan bahwa ekstrak daun asam kandis berpotensi sebagai sumber senyawa alami untuk mengatasi penyakit diabetes mellitus.

Acarbose sebagai pembanding mempunyai daya inhibisi paling tinggi yaitu $\mathrm{IC}_{50}=0,37 \pm 0,11 \mathrm{ppm}$. Tingginya aktivitas inhibisi acarbose membuktikan bahwa senyawa aktif acarbose sebagai obat antidiabetes secara efektif dapat menghambat kerja enzim $\alpha$-glukosidase. Berbeda dengan ekstrak asam kandis yang masih isinya masih merupakan campuran berbagai senyawa aktif, termasuk senyawa-senyawa metabolit primer dan penggangu lainnya berupa senyawasenyawa aktivator enzim $\alpha$-Glukosidase seperti senyawa sakarida yang berbentuk disakarida dan oligosakarida (Sugiwati, 2005). Adanya senyawa-senyawa pengotor dapat menghambat kerja senyawa aktif inhibitor enzim $\alpha$-Glukosidase karena pembentukan substrat yang jauh lebih tinggi. Pemurnian lebih lanjut terhadap ekstrak daun asam kandis diperlukan untuk mengisolasi senyawa-senyawa aktif yang khusus bertanggung jawab dalam menghambat aktivitas enzin $\alpha$ Glukosidase.

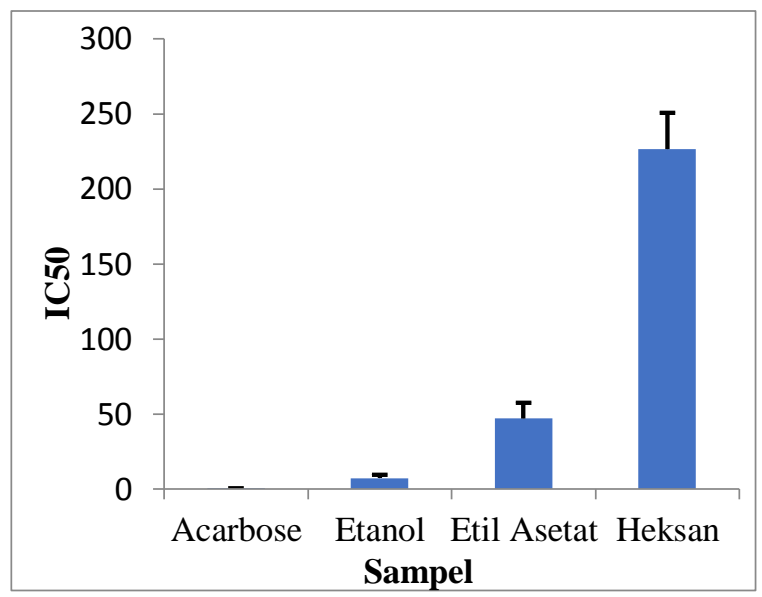

Gambar 2. Rerata Aktivitas Inhibisi Enzim $\alpha$-glukosidase $\left(\mathrm{IC}_{50}\right)$ Ekstrak Daun Asam Kandis

\section{SIMPULAN DAN SARAN Simpulan}

Dari hasil penelitian ini dapat disimpulkan bahwa ekstrak etanol daun asam kandis memiliki daya hambat paling tinggi terhadap aktivitas enzim $\alpha$ glukosidase dengan nilai $\mathrm{IC}_{50}$ 7,32 $\pm 2,14$ ppm sedangkan ekstrak etil asetat memiliki dan ekstrak heksan memiliki daya hambat lebih rendah yaitu masing-masing 46,96 \pm 10,48 ppm dan $226,47 \pm 24,18$ ppm. Hasil ini juga menunjukan bahwa ekstrak etanol daun asam kandis memiliki potensi untuk dikembangkan menjadi obat antidiabetes 
dengan mekanisme kerja sebagai inhibitor $\alpha$-glukosidase.

\section{Saran}

Perlu dilakukan fraksinasi dan isolasi terhadap ekstrak etanol daun asam kandis menggunakan metoda GC-MS atau HPLC untuk mendapatkan senyawa aktif yang lebih murni, dilanjutkan dengan uji toksisitas dan uji efektifitasnya secara in vitro dan in vivo.

\section{DAFTAR PUSTAKA}

Departemen Kesehatan RI. 1985. Cara Pembuatan Simplisia. Direktorat Jenderal Pengawasan Obat Dan Makanan. Jakarta.

Guevara, B.Q. dan B.V. Recio. 1985. Phytochemical, Microbiological and Pharmacological Screening of Medical Plant. Research Center University of Santo Tomas. Manila- Philippine.

Havsteen B.H. 2002. The biochemistry and medical significance of the flavonoids. Pharmacol Ther. 96(23):67-202.

Hsieh, P.C., H.J. Huang, Y.L. Ho, Y.H. Lin, S.S. Huang, Y.C. Chiang, M.C. Tseng dan Y.S. Chang. 2010. Activities of antioxidants, $\alpha$ glucosidase inhibitors and aldose reductase inhibitors of the aqueous extracts of four Flemingia species in Taiwan. Botanical Studies. 51(3):293-302

Irwan, F. 2011. Aktivitas antidiabetes dan analisis fitokimia ekstrak air dan etanol daun wungu. Skripsi. Bogor.

Lim, T.K. 2012. Edible Medical and NonMedical Plants: Volume 2, Fruits. Springer Science+Springer Business B V.

Liu, Y., L. Zou, L. Ma, W.H. Chen, B. Wang dan Z.L. Xu. 2006. Synthesis and pharmacological activities of xanthone derivatives as $\alpha$ glucosidase inhibitors. Bioorganic \&
Medicinal Chemistry. 14(16): 56835690.

Oussama, M.N. 2006. Guidelines for The Prevention, Management and Care of Diabetes Mellitus Ed. Oussama M.N. Khatib. EMRO Technical Publications Series 32. WHO Regional Office for the Eastern Mediterranean.

Rajendra, C.E., G.S. Magadum, M.A. Nadaf, S.V. Yashoda dan M. Manjula. Phytochemical Screening of The Rhizome of Kaemferia galanga. 2011. International Journal of Pharmacognosy and Phytochemical Research. 3(3): 6163.

Silva, M.L. 2004. Diabetes Means Siphon Insulin Comes From The Island. http://www.dightonrock. com/diabetes_history.htm. Diunduh pada 10 Juni 2012.

Smith A, Adanlawo. 2012. Hypoglycaemic effect of saponin from the root of garcinia kola (Bitter Kola) on alloxan-induced diabetic rats. Journal of Drug Delivery \& Therapeutics. 2(6):9-12

Sugiwati, S. 2005. Aktivitas antihiperglikemik dari ekstrak buah mahkota dewa (Phaleria macrocarpa (Scheff.) Boerl.) sebagai Inhibitor alfa-glukosidase. Tesis. Fakultas Matematika dan Ilmu Pengetahuan Alam, Institut Pertanian Bogor, Bogor.

Laar, F.A.V., P.L.B.J. Lucassen, R.P. Akkermans, E.H. Van de Lisdonk, G.E.H.M. Rutten dan C. Van Weel. 2005. Alpha-glucosidase Inhibitors for Tipe 2 Diabetes Melitus: A Systematic Review. Diabetes Care. 28:154-163.

Widowati, L., B. Dzulkarnain dan S. Sa'roni. 1997. Tanaman Obat untuk Diabetes Mellitus. Cermin Dunia Kedokteran. 116:53-60. 
World Health Organization. 1999.

Definition, Diagnosis and

Classification of Diabetes Mellitus and its Complications. Part 1:

Diagnosis and Classification of Diabetes Mellitus. WHO, Geneva. 
